\title{
REFORMATIE IN ROME?
}

Om deze vraag te kunnen beantwoorden, moeten we eerst vaststellen wat we onder ..Rome" verstaan. We moeten n.l. onderscheid maken tussen Ronre als kerk. ais stelsel en als verzameling van afzonderlijke mensen die lid zijn van dezelfde kerk.

\section{ROME ALS KERK.}

De vraag rijst dan onmiddellijk: Kunnen wij Rome als kerk erkennen? We weten, dat Calvijn deze vraag ontkennend heeft beantwoord. Rome mist ..de wettige gedaante van een kerk". Zie ..Institutie" van Calvijn. IV, 2. II en 12. Wel zegt Calvijn tevens dat de r.k. kerk tot ruine is vervallen, waarin we echter nog de sporen van de kerk kunnen terugvinden.

Maar geldt deze uitspraak nu nog in 1967? Vele protestanten ontkennen dit. Zij verdedigen met alle heftigheid dat Rome inderdaad ten volle als kerk erkend moet worden en noemen haar zelfs en ..zusterkerk".

Wij menen echter dat $\mathrm{cr}$ in Rome geen enkele reformatie heeft plaats. gehad, waardoor dit oordeel van Calvijn in onze tijd gewijzigd zou moeten worden. In allerlei wezenlijke punte is er nog steeds het diep-ingrijpende verschil, dat ook bestond in de tijd van Calvijn.

Daarom is het volkomen onverantwoord, wanneer protestantse kerken overgaan tot een gezamenlijke huwelijksbevestiging of Doopbediening. Samen met een k.r. priester. De onwaarachtigheid van zulk een gebeuren wil ik aantonen door een vergelijkte maken met wat ons Doopsformulier leert en de r.k. dogmatische uitspraken.

Eenzelfde Vuder?

I. Ons Doopformulier belijdt: ..Als wij gedoopt worden in de naam des Vaders, zo betuigt en verzegelt ons God de Vader, dat Hij met ons een eeuwig verbond jer genade opricht ...."

De r.k. kerk heeft echter de vervloeking uitgesproken over hen, die beweren, dat wij door Gods genade kwijtschelding krijgen van alle zondestraffen. God de Vader wil. dat wij een gedeelte van onze zondestraffen zelf uitboeten in het vagevuur. (Conc. van Trente. sess. VI can. 30). Tevens heeft de r.k. kerk met vervloeking hen veroordeeld (anathemate damnat), die beweren dat de r.k. kerk niet de macht zou hebben om door het verlenen van aflaten gedeeltelijke of volledige kwijtschelding van de straffen in het vagevuur te schenken. (Conc. Trente, sess. XXV, dekreet over de aflaat).

Deze vervloeking van Trente over die de leer van de aflaat niet willen aanvaarden, is door Paulus VI opnicuw uitgesproken in zijn Apostolische Constitutic over de aflaat, die gepubliceerd werd in de Oss. Rom. van 111 januari 1907.

De belijdenis omtrent een (jod en Vader, die uit loutere en volkomen genade de kwijtschelding verleent van alle zondestraffen, is een andere dan de belijdenis omtrent een (jod, die eerst de zondestraffen laat uitboeten (loor Zijn Z.oon en ze daarna nog eens althans gedeeltelijk door ons laat uitboten. en Dic dan aan de kelk zou hebben overgelaten om die straffen al of niet in te korten. 
2. Ons Doopformulier belijdt: „Als wij in de naam des Zoons gedoop! worden, zo verzegelt ons de Zoon, dat Hij ons wast in Zijn bloed van al onze zonden (. . . ) alzo dat wij (...) rechtvaardig voor God gerekend worden".

De r.k. kerk heeft echter uitgesproken: .Indien iemand beweert, dat de mens slechts gerechtvaardigd wordt door de toerekening van de gerechtigheid van Christus (. . . .) die zij vervloekt". (Conc. Trente, sess. VI, can. 11).

.Indien iemand beweert, dat het geloof waardoor wij gerechtvaardigd worden, niets anders is dan het vertrouwen op Gods barmhartigheid, die ons de zonden vergeeft om wille van Christus. of indien iemand beweert. dat wij alleen door zulk een vertrouwen worden gerechtvaardigd, die zij vervloekt (can. 12). „Indien iemand beweert. dat de gerechtvaardigde mens door zijn goede werken die hij verricht door Gods genade en de verdienste van Christus (waarvan hij een levend lidmaat is). niet waarlijk zou verdienen de vermeerdering van de genade. het eeuwige leven (indien hij althans in staal van genade sterft). alsook de vermeerdering van die heerlijkheid in de hemel. die zij vervloekt" (can. 32).

De belijdenis omtrent Christus, wiens gerechtigheid ons enkel wordt toegerekend door de genade en langs de weg van hel geloof, is een andere dan de belijdenis, dat wij de hemel moeten verdienen door onze goede werken.

\section{Eienzelfde II. Geest?}

3. Ons Doopformulier belijdt: ..Als wij gedoopt worden in de naam van de Heilige Geest. zo verzekert ons de $\mathrm{H}$. Cieest doot het Heilige Sacrament, dat Hij in ons wonen en ons tot lidmaten van Christus heiligen wil, ons toeëigenende hetgeen wij in Christus (. . . .). totdat wij eindelijk in de gemeente der uitverkorenen in het eeuwige leven onbevlekt zullen worden gesteld".

De r.k. kerk echter heeft de vervloeking uitgesproken over hen die beweren. dat een mens geloofszekerheid kan hebben van zijn eeuwig heil, ,.tenzij God hem dat in een speciale boodschap zou hebben gezegd" (can. 16).

De belijdenis, dat die $H$. Geest ons door het Woord Gods wil verzekeren van ons eeuwig heil. is een andere dan de belijdenis, dat de H. Geest dat slechts wil doen in uitzonderlijke gevallen en langs de weg van een speciale openbaring.

\section{Eenzelfde sakrumentsopratting?}

Ook omtrent de werking lam het sakramemt van de Doop heeft Rome een andere opvatting: .. Indien iemand beweert dat de sakramenten van de Nieuwe Wet niet door eigen werking (ex opere operato) de genade medetelen. of dat het geloof in de goddelijke belofte voldoende zou zijn voor het verkrijgen van de genade, die zij vervloekt" IConc. Trente, sess. VII, (an. 8). lk kan niet inzien, hoe een reformatorisch christen een kerk, die zulke diep-ingrijpende dwalingen onder vervlocking en met beroep op een onfeilbaar gezag heeft afgekondigd, zonder meer als wettige kerk. laat 
staan als 7.1sterkerk, kan beschouwen. Ook nu niet in 1967. want het tweede Vatikaanse ('oncilie heeft geen entele van de voornoemde dwalingen herroepen.

\section{IIEI ROOMSE STEISEI.}

\section{Mens, kerk en stelsel}

Toen mijn bock ..Moeder, ik klaag $u$ aan" in 1958 verscheen. werd het fel bekritiseerd. niet alleen van r.k. zijde. maar ook vaak door prolestanten. Ik heb echter de indruk. dat nu. acht jaar later. menig r. katholick bereid is om te erkennen. dat de kern van mijn betoog juist is geweest.

Ik heb n.l. in dat boek een zeer duidelijk onderscheid gemaakt tussen de r. katholieke mens, waarvoor ik alle liefde heb en de r.k. kerk, waarvoor ik met Calvijn nog eerbied kan hebben inzoverre er de sporen van de Kerk van Christus in zijn tcrug te vinden. enerzijds --. en het r.k. stelsel anderzijjls. waartegen mijn aanklacht zich richtte.

\section{Wat is het roomse stelsel?}

Dat r.k. stelsel had ik in mijn boek aldus omschreven: ..Onder het r.k. Stelsel versta ik de anti-christelijke tendens in die kerk. die zich langs de weg van dogmata. instellingen en massahypnose tot een zelfstandige. onverwoestbare grootheid heeft gevormd en die tot zulk een sterke macht is uitgegroeid, dat zij het Evangelie in die kerk is gaan overheersen. Ook in de protestantse kerken kunnen wij. evengoed als in de ziel van de afzonderlijke gelovigen, anti-christelijke tendenzen aanwijzen. Dat is de oude mens in de kerk en in de herboren mens. Maar deze tendenzen hebben niel via onfeilbare dogmata een geheel onafhankelijk leven gekregen.

Elke protestantse kerk stelt zich principieel onder de kritiek van het Woord van God. en daarom kan het meest geraffineerde protestantse stelsel steeds weer vernietigd worden door het tweesnijdende zwaard van dit Woord. Daarom kan men inzoverre niet van een protestants stelsel spreken" (a.w.p. 43, 5e druk).

\section{Roomse clan}

Reeds in De Bazuin van 25 april 1959 schreet prof dr. H. Cornelissen (). P.: ..Hegger ziet dat de gebreken (in de r.k. kerk) niet zuiver individueel zijn, dat wij niet alleen een $H$. Kerk van zondaars zijn. maar dat wij ook in de zonde solidair zijn, een groep vormen, een belangengemeenschap. dat er groepsegoisme bestaat. evengoed als in andere groepen. die van Adamswege solidair zijn in de eigenliefde en in allerlei gebreken die daaruit voortvloeien.

$\mathrm{Om}$ deze groepsgebreken onder een naam te brengen, voeren wij de term ..clan" in. Clan is volgens het woordenboek een stam. een gesloten groep. waarvan de meest kenmerkende trekken zijn: saamhorigheid en geslotenheid. iets goeds en iets dat veel gevaren in zich bergt. De gesloten. heid, zoals die feitelijk in allerlei clan-achtige groeperingen voorkomt, o.m. in bepaalde streken van ons land, betekent: afsluiting van andere groepen. angst voor beïnloeding, dwingelandij van regels van binnen. De clan eist dat cen lid van de clan geen geheim heeft voor zijn medeleden. ledereen kan vragen: wat doe je, waar ga je naar toe, waarom doe je dat? Het 
eigen gebied van de geest, het geheim wordt niet geëerbiedigd. De zeden en gewoonten worden diktatoriaal opgelegd; de vrijheid wordt niet voldoende geëerbiedigd".

\section{Ami-christelijke macht}

Precies datzelfde wat prof. Cornelissen ..clan" noemt. heb ik in mijn boek aangeduid met de term: r.k. stelsel tegenover r.k. kerk. Ik zou echter niet graag het woord .,r.k. clan" gebruiken.

Van de ene kant omdat dat in mijn oren grievend klinkt. Het heeft iets weg van ,kliek". En wanneer wij een ander woord voor dezelfde zaak kunnen bezigen. dat in elk geval niet kwetsend is, meen ik dat we dat moeten doen.

En van de andere kant vind ik het woord ,clan" te onschuldig. Het is een uitsluitend psychologische belichting.

Bij het r.k. stelsel is echter een sociaal-psychologische verklaring niet toereikend. De eenheid. de vastheid en de kracht van het r.k. stelsel wordt gevormd door het leerstuk omtrent het pausdom. n.l. dat deze de onfeilbare plaatsvervanger van Christus op aarde zou zijn.

Dit leerstuk moeten wij echier afwijzen als een verschrikkelijke dwaling. die Christus van Zijn plaats verdringt als het enige en waarachtige Hoofd van de gemeente, ook op de aarde. En de anti-christelijke macht, die uit deze dwaling voortvlocit en de macht van het r.k. stelsel vormt. moet ik dan ook beschouwen als een macht die zich stelt tegenover de macht. waarvan Jezus zegt: ..Mij is gegeven alle macht in de hemel, maar ook OP DE AARDE".

Daarom zie ik in het r.k. STELSEL iets van de Anti-christ tot openharing komen.

Het is hard om dit te moeten zegger. maar ik meen dat een gelovige protestant die aanneemt dat het paundom een loochening inhoudt van dc plaats van Christus op aarde. dit zo wel móét zeggen. Een MACHT, die zich in de naam van Christus. in feite stelt tegenover de MACHT, die Hem op aarde toekomt. kunnen we vanuit de Bijbel moeilijk anders zien dan als een stuk van de Anti-christ.

Voor alle zekerheid wil ik echter nog eens onderstrepen, dat ik dus niet wil zeggen dat de r.k. KERK de Anti-christ of een deel daarvan zou zijn. Het is van het grootste belang om dit onderscheid tussen KERK en STEL.SEI. goed in het oog te houden.

Ditzelfde onderscheid trof $i k$ in een andere vorm aan in De Nieuwe Linie van 22 oktober 1966 . In het artikel..Een achtenswaardig rooms man" schreet dr. F. Sierksma over de kabinetscrises. Ik citeer daaruit: De eenheid

..Voor de individuele katholick is de eenheid een heilige zaak De Eenheid. De paus heeft ei nog onlangs dringend vermanend aan herinnerd en zijn vermaan zal stellig niet zonder effekt blijven. want de eenheid is iedere rooms katholick met de moedermelk ingegeven. Schisma is een vies woord. Een buitenstaander kan soms verhhift staan kijken. ats hij een zgnl. progressieve r. katholick krıtick op zijn kerk hoost leveren. die een enkele maal niet zo ver van het blasfemische af ligt. om dan te merken. dat de betrokkene er niet aan denkt om die kerk ooit te verlaten. Dit eenheidsverlangen is bijna mysterieus. $r$....)

Voor een buitenkerkelijke is dit minder hinderlijk dan het feit, dat deze alles beheersende drang naar eenheid en geborgenheic ook het politieke leven doordringt. Iedere tegenstelling, welke ook, is ondergeschikt aan de eenheid. Dit vindt men alleen terug bij de enige andere partij die in wezen dognatisch is: de communistische". 
"De K.V.P. een onhetrouwhure partij"

Dr. Sierksma raadt de nict-rocmse poittici aan om ook wat godsdienstsociologie en godsdienstpsychologie te studeren en vervolgt dan:

.Ze zullen dan de grote betekenss van het moedersymbool in de r.k. kork begrijpen. dat samen met een autoritaire persoonlijkheidsstruktuur zo heilzaam is voor partijdiscipline Dan zullen ze begrijpen. dat individuele K.V.P-ers in de hoogvte mate betrouwbar kunnen zijn. maar dat de K.V.P. een onberroumbare partij is, moct zijn en zal zijn".

\title{
,Rome de omwaurachtige"
}

In precies dezelfde zin schreeef ik in ,.Moeder, ik klaag u aan" over de onwaarachtigheid van het roomse stelsel (p. 73-76). Ik citeer daaruit:

\begin{abstract}
..Rome heeft een uitgestrekle garderoixe. Zij heeft voor elke gelegenheid een eigen kleed. Zij hult zich in het gewaad. watin zij het meest imponeert. Nu eens treedt zij ons tegemoet in de bestikte mantel van een koningin. Maar hinnen enkile ogenblikken kin zij zich geheel omvormen en zit zij als een treurende langs de wegen. bedelend om medelijden.

Rome stelt zich aa als dz cenzame martelares der eeuwen, als de altijd weer opgejangde, als de vervolgde om Christus' wil. En zij vergeet dat de hant die zij ontkelent. meestal haar politicke macht geldt. Carribaldi heeft Rome niet betormd omdat hij Christus "ilde treffen. maar omdat hij Italie groot wilde maken. el omdat de paus met zijn wereldlijke macht hem hierin hinderde. Hij vocht tcgen de kanonnen die vanuit de muren van Rome ziju legers bedreigden. Rorre. de martelares achter de kanonnen. Rome. de onwaarachtige".
\end{abstract}

Ook heb ik in mijn boek duidelijk laten uitkomen, dat de onbetrouwbaarheid van het roomse stelsel samen kar gaan met de volstrekte betrouw. biarheid van afzomderlijke r. katholieken. n.l. p. 46-47.

Het verheugt mij. dat men langzamerhand gaat inzien. dat achter mijn publikaties geen blind antipapisme leeft gestaan, maar een bepaald sociaal-psychologisch inzicht, waarmee men het al of niet eens kan zijn. verbonden met bepaalde bijbelse overluigingen.

Het goedkope verwyt van antipapisme verhindert immers een vruchtbar gesprek over Reformatie-Rome.

De omwarachtigheid van het r.k. stelsel

Wat dr. Sierksma schreef over de K.V.P. als partij en de afzonderlijkc K.V.P.-ers, kunnen wij ook toepassen op het $r$. katholicisme als stelscl en op de afzonderlijke $r$. katholiek. We hoeven dan slechts de namen te veranderen en dan luidi onze mering aldus: ..Individuele rooms-katholieken kunnen in de hoogste mate betrouwbaar zijn. maar het rooms-katholicisme als stelsel is onbelrouwbaar, moet onbetrouwbaar zijn en zal het ook altijd zijn". Ik wil dat illustreren aan:

\section{De leugen van Jounnes $X X I I I$}

1.a Caviltá Cattolica is een zeer gezaghebbend blad ven de jezuiten. dat om de veertien dagen in Ronie verschijnt. Het is volgens T.E.U. ,.een onmisbare bron van informatie voor de kerkelijke geschiedenis van de laatste honderd jaar".

Dit blad heeft in twee artikelen aangetoond. dat het concilie geen oorspronkelijk idee was van Joannes XXIII. maar dat reeds onder Pius XI doch vooral onder Pius XII nauwkeurige voorbereidingen hebben plats gehad voor dit concilie. Deze voorbereidingen zijn echter tot aan de publicatie in Civiltá Cattolica volkomen geheim gebleven. 
Slechts 34 waren tegen een concilie.

Pius XI had aan 26 kardinalen van de Curic. 1112 aartsbisschoppen en bisschoppen en 27 prelaten en abten de vraag voorgelegd of $z i j$ een hervatting van het eerste Vatikaanse Concilie wenselijk achtten. Van de 1165 ondervraagden antwoordden er 91.3 hevestigend, 6.3 vroegen om uitstel van het concilic, en slechts 34 waren er tegen. terwijl van 154 geen antwoord binnenkwam.

En in zijn ensycliek .. Ubi Arcano" van 23 december 1923 lanceerde Pius XI aldus het idee van een algemeen concilie. ..Toch durven wij op liet ogenblik nog niet het plar vormen tot heropening van het algemeen concilie. dat door de heilige paus Pius IX begonnen is doch waarvan hij slechts een gedeelte. al is het dan een hoogst belangrijk gedeelte. heeft afgewerkt. De reden van onze aarzeling is: wij wachten. juist zoals de beroemde leider der Israëlieten. al biddende vol spanning op het ogenblik. waarop God in Zijn goedheid en barmhartigheid ons met grote zekerheid Zijn wil te kennen geeft" (Vert. E.D.).

\section{Commissies}

Pius XI had ook een commissie ingesteld ter bestudering van de mogelijkheid van het algemeen concilie. Die commissie stond onder leiding van kard. Sincero.

Voor verdere gegevens zie Civiltá Cattolica van 2 juli 1966: ..Pio XI c la ripresa del Concilio Vaticano". door G. Caprile. In Civ. Cat. van 20 aug. 1966 kunt u lezen, dat onder Pius XII de voorbereidingen voor het concilie veel intensiever werden. Er werd een centrale commissie ingesteld met vijf sub-commissies. De ontworpen schema's werden nauwkeuriger uitgewerkt.

\section{Waarom deze ontmaskering van Joannes $X X I I I$ ?}

Vanzelfsprekend stelt men zich de vraag: Waarom heeft het Vatikaan deze geheime dokumenten voor publikatie vrygegeven? De reden lijkı mij duidelijk: Paulus VI en de Curie weten heel goed dat zij zeer onpopulair zijn tegenover Joannes XXIII, die de sympathie van de hele wereld wist te winnen. Bovendien werd Paulus VI vaak vergeleken met Pius XII. En volgens ons terecht. Beiden hebben iets van de koude diplomaat.

En nu heeft men blijkbaar die verering van Joannes XXIII wat willen afremmen. Tot nog toe werd het geweldige initiatief voor het concilie alleen aan Joannes XXIII tocgeschreven. Joannes moet nu voortaan die eer delen met zijn voorgangers Pius XI en vooral Pius XII.

Vervolgens wordt Joannes enigzins ontmaskerd als een leugenaar. Want nooit heeft hij ook maar een woord gezegd over de voorbereidingen tot dit concilie die onder Pius XI en XII reeds waren getroffen. En dát terwijl Joannes XXIII zelf aan de commissie die hij had ingesteld om zijn concilie voor te bereiden, verlof had gegeven om gebruik te maken van de resultaten van de desbetreffende commissies onder zijn voorgangers. Steels heeft hij de eer voor het Tweede Vatikaanse Concilic voor zichzelf opgeëist en het zelfs voorgesteld alsof het idee hen door Godzelf was ingegeven.

"Het is me ingegeven"

Zoo heeft hij tijdens een audiënte op 11 oktober 1962 gezegd: Bij de bespreking van kerkelijke aangelegenheden met mijn secretaris is mij op zekere dag het woord concilie ontsnapt. Bij mijn dagelijkse meditatie, 
al wandelend in de tuin, is het idee blijven hangen en gedijen in mijn geest. Tegen de bezwaren van mijn omgeving in, dacht ik bij mijzelf: als het me zo spontaan te binnen is gevallen. me echt is ingegeven, dan komt het van God" (De Bazuin, 3 september 1966).

\section{Een grove leugen}

(lit de twee gedokumenteerde artikelen in La Civiltá Cattolica blijkt cus, dat Joannes bij die audiëntie twee grove leugens heeft uitgesproken. komen.

Allereerst dat het idee van het concilie spontaan bij hemzelf is opge-

Drs. Jean M. Vaissier (priester) schreef hierover in Te Elfder Ure, november 1966:
..De.hypotheticus had zich de vraitg kunnen stellen. hoe het mogelijk ware geweest, dat zulk een realist als Roncalli, na lien jatar de waarlijk niet onnozele post van nuntius in hel naocrlogse Parijs met bchoorlijk succes vervuld te hebben, de bestuullijke on-wijsheid had betoond om slechts luttele maanden na zijn pauskeuze zo iets als een Algemene Kerkvergadering le entamineren op grond van, - zoals het toeil verluidde -, een hem plotseling ingegeven idec. Ei:n algeniene wet intussen wil. dat een goed bestuuder tijn eerste jaar besteed aan orientatic. Dat gold zeker voor de Roncalli-paus wiens relaties met de Vatikaanse curic nimmer van zulk eeil intiume aard "aren geveest"

le curie was niet tegen. . .

Een andere leugen van Joannes was, dat zijn omgeving tegen een concilie zou zijn. Ook dat blijkt uit de archieven overduidelijk. De curie had zich wél het concilie heel anders voorgesteld. Ze had or heel iets anders van verwacht n.l. een veroordeling van allerlei moderne dwalingen. Daarom is het concilie voor Ottaviani en de zijnen een grote teleurstelling geworden. Maar men mag niet zeggen dat Ottaviani e.s. tegen een concilie op zichzelf was, want hij had al onder Pius XII de opdracht gekregen on de commissie te vormen, die het concilie moest voorbereiden.

\section{Een historische leugen}

Joannes XXIII had dus de geschiedenis willen ingaan met het aureool van een geinspireerde paus, van een hel den een halve martelaar die het hem door God gegeven idee wilde doorzetten tegen de druk van zijn omgeving in.

Deze historische leugen is nu ontmaskerd, ondat de tegenwoordige paus dit blijkbaar voor de verhoging van cigen populariteit en macht nodig vond. Maar hoeveel andere leugens zijn er nog altijd verborgen in de archieven van het Vatikaan? Men schermt ermee, dat het Vatikaan zijn archieven heeft opengesteld voor Ludwig Pastor, die zijn „Geschichte der Piapste" heeft geschreven. Maar het is een publiek geheim. dat Denifle van te voren oplracht had gekregen om de ergste dingen in een ...secretissiinum" onder le brengen. zoals b.v. hoe de pausen door vergiftiging om het leven zijn gebracht.

\section{"Vest op prinsen geen vertrouwen"}

Het is bijzonder vreend, dat Paulus VI, die van de historische leugen van Joannes XXIII op de hoogte was, toch gelast heeft om een proces van heiligverklaring van Joannes XXIII te beginnen. Hoe kan men iemand. 
waarvan bekend is dat hij met een ernstige leugen. die hij nooit heeft herroepen. de eeuwigheid is ingegaan, als voorbeed van heklhaftige heiligheid titroepen. - want dat betekent immers een lieiligverklaring.

Het maakı allemaal de indruk van koele berekende diplomatie. En het lijkt mij dan ook goed om hier ps. 146:3 aan te halen: ..Vertrouwt niet op prinsen. op des mensen kind bij helwelk geen heil is".

God alleen is de eeuwig-trouwe en Jezus Christus is Zijn getrouwe Getuige. Wanneer wij op Hem ons vertrouwen vestigen. zullen wij nooil beschaand uitkomen. Hij is ,.de weg. de waarheid en het leven".

\section{Joannes $X X I I I \ldots$ geen nä̈eveling}

Drs. J. M. Vaissier schrijft in T.E.U. over Joannes XXIII:

.Wat heeft hem ertoc bewogen. de mytische figuur van een goddelijke ingeving bij hed lanceren van Vatieanum 11 te kiczen. resp. van anderen te aanvaarden?

Hier zal wel nooit een dokument uitsluitsel kunnen geven. In ieder geval moet het beeld ran deze grote paus op eén punt zeker gedeniylhisecrd worden. Hij was geenzins cen naïve pastoor van Ars, tegen zijn zin en bij godcelijke gril terechtgekomen op de toel van Peırus. Bij al zijn bonhommic was onnozelheid hem vreemd. Vatikaanse insiders plachten fiem ondeugenderwijs wel .il furbo" te noemen; een Rorieinse volksuitsrukking. vrijwel overeenkonend met ons Mokumse die linke bink" ". T.E.U. p $4 . ? 0$

In gewoon Nederlands betekent, il furbo" een slımmerik. De slimmerik Joannes XXIII is er in geslaagd om ook veel protestanten om de tuin te leiden omtrent zijn ware bedoelingen; protestanten die vaak psalm 146 singen: .Vest op prinsen geen vertrouwer.”.

\section{Concilieschema's onder Pius XI en XII}

Zeer interessant zijn de ontwerpen voor het concilie die door de commissies onder de beide Piussen werden opgesteld.

In het schema onder Pius XI wordt niet gesproken over de macht van de bisschoppen. een onderwerp dat va nzulk een centrale betekenis is geweest tijdens het Tweede Vatikaanse Concilie. Dat onder Pius XII vermeldt als agendapunt: ..de oorsprong van het bisschoppelijk gezag". Voorgesteld werd o.a. om een wet uit te vaardigen tegen de priesters, die zeer zelden het sakrament van de Biecht ontvangen.

Als één van de doeleinden van het concilie werd genoend: ,.de andere schapen te voeren naar di éne schaapstal en de éne Herder" (Civ. (t. 20) aug. p. 217).

..De linke bink", Joannes XXIII wist deze bedoeling veel beter te hamoefleren.

\section{Ingekomen stukken}

Civ. Cat. vermeldt ook enkele belangrijke brieven met suggesties die waren binnengekomen. Zo b.v. van acht priesters uit Buenos Aires, die voorstelden om het verplichte celibeat af te schaffen. En ook van een anonieme Neclerlander, die crop wees, dat de werekllijke macht van de pausen gebaseerd was op een vals dokument. n.l. de z.g. ... Schenking van Constantijn", en die allc kwaien in de wereld en in de kerk toeschreef aan het romeinse recht (a.w. p. 38). 
Merkwaardig dat anonieme brieven zulk een diepe indruk kunnen maken op zulk een machlig liciaam als het r.k. bestuursapparaat te Rome. Vermoedelijk is de oorzaak daarvan geweest. dat deze .,anonimo olandese" cle spijker op de kop sloeg en de hoge heren in Rome een onrustige nachi heefi bezorgd.

\section{De romms-kallolieke mens}

Wij hebben gezien. dat or geen reformatic is gekomen in de r.k. kerk en dat een reformatie van het r.k. stelsel in wezen zelfs onmogelijk is Immers het r.k. stelsel is een bovenpersoonlijk iets. dat zich baseert op bepaalde natuurlijke driften in de mens. En de Bijbel leert ons, dat wij van nature geneigd zijn om (iod en de evenmens te haten en alleen onszelf te zoeken. Zulk een reformatie is echter wél mogelijk bij de afzonderlijke r.k. mens, of bij groepen van r. katholieken. In hoeverre het mogelijk kan zijn dat zulk een rooms-katholiek die tot waarachtige reformatie. tot innerlijke verbrokenheid des harten en tot geloof in Christus alleen is gekomen. toch nog in de r.k. kerk kan blijven. dat heb ik besproken in mijn boekje ..Moeder, ik klaag u aan" (5e druk p. 34-41). Dat wil ik hier dus niet herhalen. We gaan nu de afzonderlijke groepen na.

\section{De drie stromingen in de r.k. kerk}

Steeds duidelijke tekenen zich drie stromingen af in de r.k. kerk. Dat betekent niet, dat het drie duidelijk afgebakende groepen zijn. Toch vertonen deze stromingen ook een tendens om zich tegenover elkaar als groepen te gaan opstellen.

A. De konservatieve stroming. Deze stroming wil vasthouden aan de oude r.k. dogma's. zoals die geformuleerd zijn door de concilies en de pausen. Ze hebben een duidelijk voorliefde voor de formulering van het dogna en menen dat ook in de formule zelf iets boventijdelijks zit, wat dus niet kan veranderen. Deze stroming interpreteert die dogma's meestal vanuit een natridentijnse $(=$ na het concilie van Trente ontstane) theologie. Deze theologie was sterk rationalistisch. Dat kwam voor een groot geteelte omdat ze zich had opgesteld tegenover de reformatie. Ze meende het roonse erfgoed te moeten verdedigen tegenover de aanvallen van de reformatie. En omdat de reformatie voortdurend de nadruk legde op de Bijbel. zocht deze contrareformatorische theologie haar kracht in de argumenten vanuit de traditie en de rele. De Bijbel werd dan ook in diezelfde geest gehanteerd, n.l. als een boek waarmee men de r.k. dogmata probeerde te bewijzen. Wanneer men ziet hoe de r.k. theologische handboeken van die tijd de Bijbel mishandelen door hem met allerlei filosofische wapens te lijf te gaan. dan vraag je je met verbazing af: hoe is het mogelijk dat men gedurende eeuwen absoluut geen begerip schijnt gehad te hebben voor de eigen aard van de Heilige Schrift.

Deze konservatieve stroming heeft zich gegroepeerd in typische roomse landen zoals Spanje. Italic. Portugal en de landen van Z.-Amerika, maar merkwaardig genoeg ook in de engelssprekende landen zoals Ierland. GrootBrittannië, V.S. van Amerika. Australie en Nieuw-7eeland.

In Nederland heeft deze stroming zich gegroepeerd rondom het blad "Confrontatie". dat in Tegelen verschijnt (adm. Grotestraat 42a). Tot nog toe hebben o.a. de volgende $r$. katholieken in dit blad gepubliceerd: Prof. 
Ur. Zacharias Anthonisse, capucijn. prof. ir M. J. Granpré Molière. Henri de Greeve, de vroeger zo bekende radiospreker, dr. P. den Ottolander, een gewezen gereformeerde, dr. A. v. d. Wey, carmeliet enz.

Dr. den Ottolander is ook de ziel geweest van een aktie om een smeekschrift te sturen riaar de paus, waarin deze behoudzuchtige $r$. katholieken hun verontrusting uitspreken over de Nieuwe Katechismus van de Nederlandse bisdommen.

Voor het konservatieve r. katholicisme van Engeland is het dan ook een vreselijke schok geweest, toen in december 1966 hun meest befaande theoloog. prof. dr. Charles Davis, de r.k. kerk verliet. Vooral ook omdat dit uittreden met enorm veel publiciteit gepaard ging via pers. radio en zelfs televisie. De engelse correspondent van De Tijd schreef dan ook verbitterd, dat dr. Davis niet zo in het openbaar had mogen spreken over de redenen, waarom hij de r.k kerk had verlaten. Dat was ,een bevuilen van het eigen nest".

Merkwaardig zulk een uitspraak, terwijl de r.k. kerk in het verleden cen intense propagande voerde met protestanten die overgingen naar de r.k. kerk. De bekende Newman werd verheven tot de waardigheid van kardinaal en in onze tijd gaan er zelfs stemmen op om hem te laten heilig verklaren.

B. De bijbels-progressie stroming. Deze stroming probeert de oude r.k. dogma's te vullen mei een nicuwe, meer bijbelse inhoud.

Zelf heb ik tijdens mijn theologiestudies de overgang tussen die beide stromingen vrij scherp beleefd. We hadden eerst een professor, die de theologie doceerde op een volkomen dorre scholastische manier. Daarna hregen we dr. Chr. Oomen, die ons leerde om allereerst na te gaan wat de Bijbel over een onderwerp zegt.

Ik vond deze benadering van $\mathrm{dr}$. Oomen veel rijker en warmer. Hij was echter erg verward tegenover de dorre, maar toch wel scherpe analyse van zijn voorganger.

$\mathrm{Na}$ de oorlog is deze stroming echter steeds sterker geworden en op het tweede Vatikaanse Concilie bleck zij reeds zo sterk te zijn dat zij zich als de progressieve groep wist op te steilen tegenover de konservatieve groep, die vooral door Paulus VI en de romeinse Curie vertegenwoordigd werd. De spanningen die daardoor op het concilie onstonden, hebben we $\checkmark$ ia de pers kunnen volgen.

$\mathrm{Na}$ het concilie is deze stroming nog sterker geworden. Men durfde het op de duur aan om alle dogma's aan een kritick vanuit de Bijbel te onderwerpen.

\section{Beziming op de onfeilhaurheid}

In De Bazuin van 27 aug. '66 stond een weergave van een zeer interessante lezing van Jr. J. J. C. Willense. waurin deze zocht naar een nieuwe interpretatic van de onfeilbaarheid van de r.k. dogma's. Hij ziet die onfeilbaarheid slechts als cen negatieve garantie. In deze zin:

.W de dus dic bepaalde leer als war anvaardi. behoefte niet bang te zijn dacurdoor ontrouw te zijn aan (hristus, aan (iod Dit betekent echter nog riet. dat wie die bepailde leer nog niet ziet, dat wie die bepaulde leer niet (zonder meer) als waar aanvaardt, dus daardoor wel ontrouw aan 
Christus. aan God zou zijn. Het betekent zelfs niet dat die bepaalde leer werkelijk en zonder meer waar is. De ohjektieve waarheidswaarde van die leer als een geheel tan beweringe'n is en blifft dan dus. althans principicel, ler discussie". open voor ieder ecrlijk en kritisch vragen".

De oude eis van het ,onvoorwaardelijk en blind aanvaarden van onfeilbare uitspraken" wordt volgens W. .én voor vele gelovigen én voor steeds meer priester en theologen een onmogelijk en willekeurig ..offer van het intellekt". waarvan ik niet zie hoe men dit kan laten zien als evangelische opgave". Wanneer deze interpretatie van dr. Willemse officieel zou worden toegestaan, dan zou er voor het eerst een wezenlijke verandering in r.k. opvattingen plaats vinden, die Rome een heel eind dichter bij de Reformatie zou brengen.

Immers ook wij aanvaarden dat Christus met Zijn gemeente is tot aan het einde der tijden. En al aanvaarden wij niet de onfeilbaarheid van de kerk in dezelfde zin als Rome dat steeds heeft verstaan, toch weten ook wij dat de poorten der hel de gemeente van Christus niet zullen overweldigen en dat de waarachtige gemeente van Christus nooit tot de volstrekte dwaling kan vervallen.

Deze paus zal zulk een opvatting echter zeker niet officieel toestaan.

\section{De mis}

De bijbels-progressieve groep is ook anders gaan denken over de tegenwoordigheid van Christus in de mis. Het concilic van Trente had n.l. vastgesteld. dat brood en wijn wezenlijk veranderen in het lichaam en bloed van Christus en dat deze verandering het beste kan worden aangeduid door de term ,transsubstantiatie". Tot voor kort werd dat zo opgevat, dat door de woorden van de priester in de mis een wonderlijke verandering plaats greep in het brood en de wijn.

Deze groep denkt daar echter anders over. Zij zeggen: Brood en wijn blijven brood en wijn in de mis. $\mathrm{Er}$ is geen sprake van een soort wonder.

Wat verandert dan? De bestemming en de betekenis van brood en wijn. Normaal dienen ze om het lichaam van de mens te spijzigen en on de dorst te lessen. Bij de mis (en het Avondmaal) verandert die bestemming. We gebruiken dat brood daar niet met de bedoeling om onze honger te stillen en de wijn niet om onze dorst te lessen. Brood en wijn krijgen daar een andere betekenis. Zij symboliseren het lichaam en het bloed van Christus. Daarom heeft het eten van dat brood en het drinken van die wijn ook een andere bestemming. n.l. om het komen van Christus tot Zijn gemeente uit te drukken, Zijn vertroostende nabijheid.

Wanneer dan de konservatieve richting hun voor de voeten werpt: Maar Trente heeft toch als dogma vastgesteld, dat brood en wijn in de mis cen wezenlijke verandering ondergaan, dan is hun antwoord: Inderdaad, maar het wezen van brood en wijn bestaat in de bepaalde stemming voor de mens, n.l. on zijn honger te stillen en zijn dorst te lessen. Wanneer nu die wezenlijke bestemming verandert, zoals dat gebeuri bij het Avondmaal (de mis), dan heeft er dus ook een wezenlijke verandering plaats van brood en wijn. Wij komen met onze opvattingen dus niet in konflikt met 'Trente. 
Het eerste Vatikaanse concilie had deze begripsbepaling gegeven van wat geloof eigenlijk is: .. Het geloof dat de aanvang is van het menselijk heil, is een bovennatuurlijke deugd. wilardoor wij. onder de inspiratie en met de hulp van God. geloven dat wat $\mathrm{Hij}$ geopenbaard heefı. waar is. niet op grond van een inzicht in de waarheid van die dingen dat wij met het licht van de natuurlijke rede zouden hebben verworven. maar op grond van het gezag van Ciod zelf die het ons openbaart. en die niet bedriegen kan en ook niet bedrogen kan worden".

In deze begripsbepaling valt alle nadruk op het aannemen van de geopenbaarde waarheden en wordt met geen woord gerept over de wederharende kracht van het geloof. zoals de Bijbel ons dat ontvouwt.

Door hernieuwde studie van de Bijbel is men echter gaan zien. dat men aldus ernstig tekort doet aan de rijke heilsfunktie van het geloof.

Interessant is in dit verband een artikel van de Spaanse theoloog prof. dr. J. Alfaro in .Concilium" jan. 1967 p. 5()-63. Hij zegt daarin o.a.: ..De moderne hijbelvereklaring erkent. dat zowel ir het Oude Teslament als in het Nieuwe Testament het geloof het alles omvattende antwoord van de mens is atan (jod. die zich als Zijn Verlosser openhaart. en dat dit antwoord de aanvaarding inhoudt van de heilshoodschap van God en de toegewijde "nderworpenheid aan zijn woord". (p. 52). .DE vergave alan Gind in gehoorzaamheid en vertrouwen is geen bijverschijnel van het geloof. maar makak er juist de kern ran uit. Door ons onbeperkt zijn liefde te laten zien in het offer van Zijn eigen /oon. nodigt God ons ait om ons volledig aan Zijn barmhartigheid over te geven (Rom. 5:8-10: 8:31-39): het geloof in God, onze Verlosser door Jezus (hristus. kan niel anders dan het vertrouwen in Hem insluiten" (p. 554)

Natuurlijk zitten ook deze r.k. theologen dan weer met de kerkelijke logma's, die niet goed te verenigen zijn met deze nieuwe bijbelse opvattingen. Zo b.v. heeft de r.k. kerk gedogmatiseerd, dat dit echte bijbelse geloof in de mens aanwezig kan zijn zonder dat hij God waarachtig liefheeft, maar Hem dus integendeel haat.

Prof. Alfaro doet een poging om daar een antwoord op te geven als hij schrijft:

.Het kerkelijk leergezag heeft bepaald. dat het verlies van Gods vriendichap door de zonde nict noodzakclijk in de mens de verdwijning van het geloof meebrengt. Maar hieruit volgt niet dat het geloof kan bestaan zonder te streven naar de liefde van (ind: dat geloof houdt noodzakelijk het verlangen niaar redding in. (- ). D: afwezigheid van de liefde betekent voor het geloof zelf een Jodehijke wond en belast de gelovige met een inwendige spanning. dic ofwel 'n een verzoening met God of door een radicale keuze voor de ongelovigheid en scheiding mu (jod pgelost zal moeten worden" p. 55).

Wij kunnen blij zijn met deze poging, maar we zullen toch eerlijk moeten zeggen dat dit geen antwoord is. Want als wij de liefde Gods niet bezitten. dan zijn wij dood in onze overtredingen en misdaden, zegt de Bijbel. Dan is er ook geen streven meer in ons naar de liefde Gols. We kunnen daar wel wat mooi omheen filisoferen. maur zo zegt de Bijbel hel. Wie geestelijk dood is, kan en wil God niet liefhebben.

Maar hoe het ook zij, wij verblijden ons erover dat deze r.k. theologen toch een antwoord op deze vragen in de Bijbel zelf zoeken.

C. De vrijzinnige stroming. Wii zouden nog meer voorbeelden kunnen geven van pogingen van r.k. theologen om de oude r.k. dogmata te vullen met een nieuwe bijbelse inhoud. maar dan zou dit hoofdstuk te lang 
worden. We moeten n.l. ook nog aandacht besteden aan de vrijzinnige stroming. die de r.k. dogmata probeert te vullen met een puur humanistische. sons bijna atheistische inhoud.

Want helaas is deze groep steeds sterker aan het worden binnen de r.k. kerk. Wij willen daar enkele voorbeelden van geven.

\section{Ioochening van de erfzonde}

Dr. A. Hulsbosch in De Bazuin. 9 oktober 1965.

.. In het licht vare de huidige kemns van de ontwikkeling van het leven is het standpunt onhoudbiar dat de stamouders rolmaakle mensen geweest zouden zijin. in staal tot een zedelijke beslissing van zo diep ingrijpende aard. dat de menshed in haar geheel onder de gevolgen gebukt gaat. Dit hecld van de ecrste mensen strookt niet niet de wetenschap dat de mens zich heeft entwikkeld uit een vocrafgaande dierlijke soort. Dit alles brengl mee, dat hel jogma van de erfzonde niet meer verkondigd kan worden in de iraditioncle formul::"

De Nieuwe Katechismus ... in opdracht van de bisschoppen van Nederland. pag. 3()9:

.. ()ns wereldbecld is echter veranderd. Wij hehben wijder overzicht over het verre verleden". ..Het hegin is dus minder belangrijk voor ons dan vroeger. (Ook wal ce zonde beireft is dit zo. We behoeven niet een bijzondere belekenis toe te kennen ala de ecrste zonde".

De Adam lan het Bijhelverhaal heeft nooit bestam Tot deze kon. klusie komt dr. A. Hulsbosch in De Bazuin van 2 okt. 1965:

..Terwijl de auteus van hel paradijsterhaal zijn eesste mensen tekent als harmonische persoonliikhedeit. levend in een ideale wereld. zullen wij in hel licht van de evolutietheorie de eerste mensen moeten plaatsen in een vijandige wereld. Waarbinnen zij zich bewegen met een nauwelijks doorbrekend verstandelijk vermogen. in het bezit van een daarnee overeenkomstige. 7eer heperkte graad van zedelijk hewustıijn."

\section{I.oochening van de opstanding van Christus}

Drs. Weterman in: Ter Discussia. Wereld en Kerk. blz. 4-5: .Is de Heer werkelijk 'errezen?"

De Kerk klamp zich op ontoelaatbare wijze vast aan vermeend bovellmenselijke invloeden: ontoelaatbaar. omdat daardoor binnen het vlak der schepseloorzakelijkheden en der menselijke moliveringen bovennatuurlijke invloeden worden ingevoegd. Engelen gaan rond als hoodschappers Gods. demonen vormen hun tegenspelers. Verhalen doen de ronde omtrent wonderen in de zin van mirakelen. d.i. gebeurtenissen. waarbij door ..direkte invlod Gods" een gaping hinnen hel geheel van schepselinvloeden wordt aangevuld (men denke slechts aan beide .hoekwonderen van het Nieune Testament. het lege graf en aan de andere zijde de maagdelijke geboorte. waarhij (iods (jeest bij de moeder aanvult wal aan mannelijke inbreng ontbreekt). Aan de verheerlijkte mens Jezus wordt cen onrzakelijke invloed op het heden toegekend on dit te verlossen uit zijn erfzondelijke konditie. d.i. .de situatic van een slechts sakramenteel op te heffen gemis aan bovennatuurlijke genade. Waarin de mens zich hevindt sinds en door hel feil dat de bondsbreuk met (iod zich hestendigd heeft in de verwerping van ("hristus" (Schoonenterg. Schillebeekx). De voorbeclden zouden gemakkelijk le vermeerderen zijn. In een woord: de kerk lecft van myile't. die voor hedendaagse levenshesef als onvolerekhat verschijnen"

\section{Ilet lijk van Christus vergaun?}

In De Bazuin van 22 jan. 1966 schreef drs. Alb. Renckens: .In de getuigenis of prediking komt de nadruk dan ook vooral te liggen op Zijn verechijnen of 7 ijn verresen-zijn-voor-ons. dat pas enkele dagen na zijn dood plaats vindt. Het al of niet arwezig zijn onder ons van wat eers 
Zijn tijdelik lichaam of bestaan is geweest (...), heeft dan niet de minste betekenis. St. Paulus b.v. spreekt dan ook nooit van het lege graf. Waarschijnlijk (hier moeten echier de exegeten gehoord worden) is Zijn lijk toch ergens geweest en vergaan".

\title{
Maagdelijke geboorte van Christus betwyfeld
}

Nieuwe Katechismus, p. 90:

\begin{abstract}
..Christus werd geboren geheel uit genade, geheel uit belofte: .ontvanger van de heilige Geest". Het geschenk van God aan de mensheid.

Dit drukken de evangelisten Mattëus en Lucas uit als zij verkondigen dat Jezus niet door de wil van een man ontstaan is. Zij verkondigen hoe deze geboorte, oneindig meer dan die van enig mensenkind, in geen enkele verhouding staat tot dat wat de mensen uit zich kunnen. Dat is de diepe zin van het geloofsartikel: Geboren uit de maagd Maria".
\end{abstract}

Prof. dr. P. Schooneberg S. J. in De Tijd van $17 \mathrm{dec}$. 1966:

"Het Nieuwe Testament als geheel wekt de indruk dat de maagdelijke geboorte een dichterlijke uitdrukking is van Jezus' unick goddelijk zoonschap".

\section{Loochening van het voortbestaan na de dood}

..Er is een tijd geweest. waarin men (iod nodig had als fundament van do moraal, want. zo meende men: „Als (iod niet bestaal, is alles geoorloofd". Mar ook hier heeft men afstand van gedaan. en ervaren dat de mens zelf moet uitmaken wat goed en kwaad is, en dat hij daartoe ook het vermogen heeft".

De ,christelijke" hoop

Drs. M. C. Ryk in De Basuin van 12 nov. 1966:

"Is de christelijke hoop niet de hoop dat dit aanvaarden, dit accepteren van de eindigheid mogelijk zal zijn voor de mens? Is het niet de hoop en daarin reeds de zekerheid dat voor de mens mogelijk is in vrede te sterven. tevreden te sterven en zich te verzoenen met de dood en het einde? Men zou kunnen opwerpen: genoegen nemen met de eindigheid is toch onmogelijk! Maar is dit wel onmogelijker dan genoegen te nemen met een „eeuwige hemel" waar we niets van begrijpen?"

Pluk de dag

Zo schreeef deze priester, die volgens de r.k. kerk „een andere Chrislus" is:

„Door te spreken van een hemel en een hel na dit leven, stelt men het geluk uit of maakt men de mens angstig. Tijdens zijn leven moet de mens gelukkig kunnen zijn om zijn aardse leven en aardse voortleven door het goede dat hij deed, de solidariteit welke hij tot stand hielp komen. Hoe meer de mens afstand kan doen van de droom over een leven na dit leven, des te meer zal hij zich hasten hier zelf gelukkig te zijn en het anderen te laten zijn".

Wanneer je dat alles leest, kun je daar diep bedroefd om worden. Bedroefd omdat aldus de heerlijkheid van onze God en Zaligmaker Jezus Christus geloochend wordt. Bedroefd omdat de kracht van Zijn opstanding geloochend wordt, die de enige hoop is voor ons leven. Bedroefd ook om de troost die daardoor voor zovelen geroofd wordt.

In een van de nummers van De Bazuin volgend op dit artikel van pater Rijk worden allerlei reakties opgenomen van $r$. katholieken, sommige heel fel, die aan pater Rijk verwijten dat hij in feite een atheist is.

Onder deze reakties ook van twee scholieren van de middelbare school. 
Een meisje van 16 jaar antwoordde op de troosteloze „boodschap" van pater Rijk met een hartverscheurend gedicht:
„Langzaam val je uit elkaar
Een hol-ogig akelig gezicht
Het is een dode die daar ligt
Misschien een meisje zoals ik
In het gezelschap van allerlei dieren
Die haar dood komen versieren
Onder het zand in een kist
God als u eens wist
Hoe groot mijn angst is."

Een jongen van 15 jaar schreef:

..Dan lig je daar (na je dood), met je armen tegen je koude lijf, mijn liefde wat wil je nog meer. Zo denk ik er ook over. Je hoeft je nergens meer wat wan aan te trekken. nergens geen zorgen meer over te maken. Waarom pleeg je dan geen zelfmoord, on het zo maar eens te zeggen, zult u dan vragen. Daar heb ik geen moed voor en ook om een tweede reden niet. Ik heb zelf meegemaakt hoe mijn zusje drie jaar geleden verdronk. wat volgens mij mijn schuld was. Toen kwamen ze thuis bij mijn moeder en die was radeloos".

\section{Spanmingen tot op het geheente lan de r.k. kerk}

U kunt dan ook begrijpen, dat de r.k. kerk op dit monent in uiterste spanning leeft. Het is een kerk die op springen staat. Dat is wel erg duidelijk geworden o.a. uit een artikel van Drs. J. Arts in De Haagse Courant van 4 febr. 1967, waaraan ik het volgende ontleen:

,De gebeurtenissen binnen de r.k. kerk lijken de laatste tijd minder hepaald door de tegenstelling die men tijdens het Vatikaanse Concilie (1962-1965) .progressiel-konservatief" noemde en die meer of minder aanpassing van de situatie op het oog had. $E_{r}$ is thans sprake van radicalere. wezenlijker zaken. De nieuwe spanning gaat veel dieper en raakt het historisch gebeente van de katholieke kerk".

„De liturgiedeskundige pater H. Oosterhuis S. J. verklaarde:

- Als Rome zo doorgaat, kan het voor heel wat priesters betekenen, dat zij over en paar jaar niet meer voor hun geweten verantwoord zijn om r.k. priester te zijn -".

„Tien, zelfs vijf jaar geleden zou het „uittreden” van een man als Charles Davis, een befamade Engelse priester-vaktheoloog, nog gehuld zijn in een sfeer van stilzuijgen. Nu echter gaat een respectabele theoloog als pater A. R. Adolfs, wiens boeken een internationale markt vinden, er in het openbaar vitvoerig op in. Hij vraagt zich af, waarom hij zelf (nog) niet dezelfde stap wil zetten. Hij geeft daarvoor tastenderwijs een aantal redenen. Maar hij eindigt:

- Na dit alles geschreven te hebben. vraag ik me toch nog af, of die .anderen" eigenlijk niet moediger zijn dan ik. Maar voorlopig heb ik nog geen beter antwoord gevonder. op de vraag: Heer, tot wie zouden wij gaan?"-".

Tot wic zouden we guan?

Wat een ernstige vraag. Ze spreekt tot ons geweten. Ze roept ons op on overal, ook aan deze worstelende r.k. priester, de Christus der Schriften te verkondigen. Immers alleen bij Hem vinden wij rust.

Maar intussen rocpt de paus de $r$. katholieken op om naar hem te komen. Hij wijst op zichzelf en zegt: Hier is de Christus. Ik wil dit hoofdstuk dan ook eindigen met een artikel dat ik schreef in ..In De Rechte Straat" van maart 1967: 
Hier is de Christus - (ielooft gij dat?

In zijn rede tijdens de algemene audientie van 12 jan. 1967 wees Paulus VI op zichzelf en zei: "Zie, hier is de stem lan de I/eer" en stelt daarna de vraag van Jezus aan Martha: ,Cielooft gij dat" (Joh. 11:26). Aldus. Oss. Rom. 12 jan.

Ons antwoord: Neen. paus, dat geloven wij niet. Waarom? Omdat de Here in Zijn Woord heel andere dingen zegt dan u verkondigt. De Here is een barmhartige en goede Herder, die zijn schapen om niet voert naar de grazige weiden. Jezus beschermt Zijn schapen tegen de aanvallen van de vreende. tegen de dief en de wolf. Maar u gebruikt de staatsmacht. o.a. van ltalië en Spanje, on de vrijheid van de schapen van Christus aan banden te leggen.

..Ik ben de goede herder en lk ken de mijne en de mijne kennen Mij”. ..De schapen volgen hem ondat zij zijn stem kennen; maar een vreemde zullen zij voorzeker niet volgen. doch zij zullen van hem weglopen, ondat zij de stem des vreemden niet kennen" (Joh. 10:14, 4-5).

De stem van de goede llerder. Wij herkennen in uw stem niat de stem van onze goede Herder. Jezus. Die stem is heel anders dan de uwe. De stem van Jezus is vol lieflijkheid, vol waarheid en genade. Die stem klinkt in ons door Zijn Woord en door de vertroosting van Zijn Geest die in ons woont.

Maar u bedreigt ons met het vagevuur. I tracht ons van uw gunsten afhankelijk te maken door de aflaten, terwijl wij weten dta wij slechts afhankelijk zijn van de eeuwige. soevereine gunst van de hemelse Vader, die Hij ons in Jezus Christus betoont.

$U$ hent een valse christus. Daarom geloven wij het niet, als u op uzelf wijst en zegt: ..Hier is de stem van de Heer" En in de naam van Jezus Christus klagen wij u aan voor zulk een vermetelheid en wij roepen u de woorden van onze Here toe: ..Indien dan iemand to u zegt: Zie, hier is de Christus. of: Hier, gelooft het niet. Want er zullen valse christussen en valse profeten opstaan en zij zullen grote tekenen en wonderen doen. zodat zij, ware het mogelijk, ook de uitverkorenen zouden verleiden" (Matth. 24:23-24).

U, Paulus VI, mijnheer Montini, bent een valse christus en u tracht velen te verleiden, zodat ze voor u neervallen en uw voeten kussen. En u slaagt daar voor een gedeelte in.

Niemand rukt ons uit Kijn hand. Maar u zult geen uitverkorenen Gods kunnen verleiden. Wij kennen de belofte van Christus: ..Mijn schapen horen Mijn stem en Ik ken ze en zij volgen Mijn en Ik geef hun het eeuwige leven; en zij zullen niet verloren gaan in der euwigheid, en niemand zal ze uit Mijn hand rukken" (Joh. 10:27-28). Jezus.

Niemand zal ons kumnen rukken uit de hand van de goede Herder.

Ook u nict, mijnheer Montini in Rome.

(Gelewer voor G.T.V., Pretoria.)

H. J. Hegger. 